OPEN ACCESS

Edited by:

Junkal Garmendia,

Consejo Superior de Investigaciones

Científicas (CSIC), Spain

Reviewed by:

Jose Yuste,

Instituto de Salud Carlos III, Spain Kristian Riesbeck,

Lund University, Sweden

*Correspondence:

Jeroen D. Langereis

Jeroen.Langereis@radboudumc.nl

Specialty section:

This article was submitted to

Microbial Immunology,

a section of the journal

Frontiers in Immunology

Received: 07 June 2018 Accepted: 06 August 2018 Published: 23 August 2018

Citation:

Langereis JD, van der Flier $M$ and de Jonge MI (2018) Limited Innovations

After More Than 65 Years of Immunoglobulin Replacement

Therapy: Potential of IgA- and IgM-Enriched Formulations to Prevent Bacterial Respiratory Tract Infections.

Front. Immunol. 9:1925. doi: 10.3389/fimmu.2018.01925

\section{Limited Innovations After More Than 65 Years of Immunoglobulin Replacement Therapy: Potential of IgA- and IgM-Enriched Formulations to Prevent Bacterial Respiratory Tract Infections}

\author{
Jeroen D. Langereis ${ }^{1,2 *}$, Michiel van der Flier ${ }^{1,2,3,4}$ and Marien I. de Jonge ${ }^{1,2}$ \\ ${ }^{1}$ Section Pediatric Infectious Diseases, Laboratory of Medical Immunology, Radboud Institute for Molecular Life Sciences, \\ Nijmegen, Netherlands, ${ }^{2}$ Radboud Center for Infectious Diseases, Nijmegen, Netherlands, ${ }^{3}$ Pediatric Infectious Diseases and \\ Immunology, Amalia Children's Hospital, Nijmegen, Netherlands, ${ }^{4}$ Expertise Center for Immunodeficiency and \\ Autoinflammation (REIA), Radboudumc, Nijmegen, Netherlands
}

Patients with primary immunoglobulin deficiency have lower immunoglobulin levels or decreased immunoglobulin function, which makes these patients more susceptible to bacterial infection. Most prevalent are the selective IgA deficiencies ( 1:3,000), followed by common variable immune deficiency $(\sim 1: 25,000)$. Agammaglobulinemia is less common $(\sim 1: 400,000)$ and is characterized by very low or no immunoglobulin production resulting in a more severe disease phenotype. Therapy for patients with agammaglobulinemia mainly relies on prophylactic antibiotics and the use of lgG replacement therapy, which successfully reduces the frequency of invasive bacterial infections. Currently used immunoglobulin preparations contain only lgG. As a result, concurrent IgA and IgM deficiency persist in a large proportion of agammaglobulinemia patients. Especially patients with IgM deficiency remain at risk for recurrent infections at mucosal surfaces, which includes the respiratory tract. IgA and IgM have multiple functions in the protection against bacterial infections at the mucosal surface. Because of their multimeric structure, both IgA and IgM are able to agglutinate bacteria efficiently. Agglutination allows for entrapment of bacteria in mucus that increases clearance from the respiratory tract. IgA is also important for blocking bacterial adhesion by interfering with bacterial adhesion receptors. IgM in its place is very well capable of activating complement, therefore, it is thought to be important in complement-mediated protection at the mucosal surface. The purpose of this Mini Review is to highlight the latest advances regarding IgA- and IgM-enriched immunoglobulin replacement therapy. We describe the different IgA- and IgM-enriched IgG formulations, their possible modes of action and potential to protect against respiratory tract infections in patients with primary immunoglobulin deficiencies.

Keywords: IgM, IgA, IgG, immunoglobulin replacement therapy, respiratory tract infections, primary immunodeficiencies, complement system proteins, bacterial infections 


\section{ROLE FOR IMMUNOGLOBULIN SUBCLASSES IN PROTECTION AGAINST BACTERIAL INFECTIONS}

Immunoglobulin production by B-lymphocytes is a sophisticated adaptive immune defense mechanisms evolved in jawed vertebrates (1). The absolute importance for immunoglobulins in protection against infections is illustrated in patients that completely lack immunoglobulin production, which is a lethal condition due to increased susceptibility for invasive infection (2). There are 5 main classes of immunoglobulins; IgG, IgM, IgA, $\operatorname{IgD}$ and IgE, all having different properties and functions (3). For this Mini Review, we will focus on IgG, IgM, and IgA and their role in protection against bacterial respiratory tract infections.

Immunoglobulins are with $10-22 \mathrm{~g} / \mathrm{L}$ a major serum constituent. The majority of serum immunoglobulins are $\operatorname{IgG}$ ( $\sim 75 \%)$, followed by IgA $(\sim 15 \%)$ and IgM ( $\sim 10 \%)(4)$. IgG can be subdivided into IgG1, IgG2, IgG3 and IgG4 and IgA can be subdivided into IgA1 and IgA2. The half-life of immunoglobulins vary, with 3 to 4 weeks for IgG1, IgG2 and IgG4, whereas this is around 2 weeks for $\operatorname{IgG} 3(5,6)$. Half-life for $\operatorname{IgA}$ and $\operatorname{IgM}$ is with 5 to 6 days much shorter compared to $\operatorname{IgG}(6,7)$.

The different immunoglobulins have specific functions in immunity. Upon binding to their targets, both IgG and IgM are capable of activating complement through binding of C1q. The ability to activate complement for IgG subclasses varies due to differences in $\mathrm{C} 1 \mathrm{q}$ binding, which is highest for IgG3, followed by $\operatorname{IgG} 1, \operatorname{IgG} 2$ and is absent for $\operatorname{IgG} 4(8,9)$. Recent data indicate that IgG oligomerizes into hexamers, forming an optimal configuration for C1q binding (10). This oligomerization might explain the more efficient activation of complement by $\operatorname{IgM},(11-13)$ because it is present as polymeric structures (pIgM) (14).

IgA is not able to activate complement directly. There are two subclasses of $\operatorname{Ig} \mathrm{A}, \operatorname{Ig} \mathrm{A} 1$ and $\operatorname{IgA} 2$, characterized by differences in their hinge region (15). Whereas IgA1 is the predominant subclass in serum, both IgA1 and IgA2 are present on the mucosal surface (16). The majority of $\operatorname{IgA}$ at the mucosal surface is dimeric ( $\operatorname{dgA})$ (16), whereas the majority in serum is monomeric (17). IgA is most abundant at mucosal surfaces where it has a role in protection against toxins, viruses and bacteria by means of direct neutralization, or by preventing attachment to the mucosal epithelium $(18,19)$.

IgA and IgM can be transported to mucosal surfaces through the polymeric immunoglobulin receptor (pIgR) (20). Only polymeric immunoglobulins containing a J-chain can be transported by this receptor (21). The pIgR present on the basolateral side of epithelial cells binds $\operatorname{dIgA}$ and pIgM, which facilitates transcytosis to the apical side, where it is cleaved off

Abbreviations: Btk, Bruton tyrosine kinase; CVID, Common variable immune deficiency; dIgA, Dimeric IgA; FcRN, Neonatal Fc receptor; FFP, Fresh frozen plasma; IgGRT, IgG replacement therapy; IgRT, Immunoglobulin replacement therapy=; IM-IgGRT, Intramuscular IgG replacement therapy; IV-IgGRT, Intravenous IgG replacement therapy; PID, Primary immune deficiencies; pIgM, Polymeric IgM; SC-IgGRT, Subcutaneously IgG replacement therapy; sIgA, Secretory IgA; sIgAD, Selective IgA deficienciy; sIgM, Secretory IgM; sIgMD, Selective IgM deficienciy; XLA, X-lined agammaglobulinemia. and leaving the secretory components attached, resulting in the formation of secretory $\operatorname{IgA}(\operatorname{sIgA})$ or $\operatorname{SIgM}(22,23)$. Association of the secretory component enhances resistance to proteolysis (24), but does not affect the ability to activate complement (25).

IgG is not transported by the pIgR, but through the neonatal $\mathrm{Fc}$ receptor $(\mathrm{FcRn})(26)$. FcRn is able to transport IgG from the basolateral to the apical side, and vice versa (27). This FcRnmediated retrograde transport and recycling of IgG is thought to contribute to the prolonged half-life in serum $(28,29)$.

A successful strategy to protect healthy individuals from respiratory tract infections is the use of vaccination. In the early 1990s, the Haemophilus influenzae serotype B (Hib) conjugate vaccine entered the market, which decreased invasive Hib disease cases substantially in many countries (30-33). This Hib conjugate vaccine is highly immunogenic and increases capsule-specific antibody levels that not only protects against disease such as pneumonia and meningitis, but also against nasopharyngeal colonization (34). Hib vaccination elicits a combination of serum immunoglobulin subclasses, mainly IgG, but also IgM and IgA (35). Vaccination of children with the Streptococcus pneumoniae polysaccharide conjugate vaccines (PCV) has shown to increase capsule-specific IgG antibody levels (36) and confer protection against nasopharyngeal colonization, otitis media, pneumoniae and bacteremia (37-39). Vaccine-induced polysaccharide capsule-specific antibodies initiate complement deposition on the bacterial surface, which is essential for opsonophagocytic killing of $S$. pneumoniae and $H$. influenzae in whole blood (40).

\section{IMMUNOGLOBULIN DEFICIENCIES}

The diverse roles of the different immunoglobulin subclasses in protection against infections is illustrated in patients with primary immune deficiencies (PID), as described in more detail below.

\section{Selective IgA Deficiency}

Selective $\operatorname{IgA}$ deficiency ( $\operatorname{IgAD}$ ) is characterized by serum $\operatorname{IgA}$ level of $<7 \mathrm{mg} / \mathrm{dL}$, with normal levels of both IgG and IgM in individuals more than 4 years of age (41). Most patients are clinically asymptomatic, but others show recurrent infections, allergies and autoimmunity (2). Although rather prevalent, the exact pathogenesis is unknown. Since sIgAD is heterogeneous in presentation of disease symptoms, it is likely that different aetiologies might be involved in the cause of this disease. There is evidence for genetic predisposition based on familial clustering, and mutations in many genes involved in cellular and humoral immunity have been associated with SIgAD (42).

Recurrent respiratory tract infections are the most common disease associated with $\operatorname{SIgAD}(43-45)$. When divided into complete and partial IgA deficiency, a history of chronic or recurrent infections is more often found in patients with complete IgA deficiency (77\%), compared to partial IgA deficiency (20\%) (44), suggesting that a lower IgA is associated with frequent infections. Elevated levels of IgG or IgM are found in a proportion of sIgAD patients (44-47), which might compensate the IgA deficiency. Patients with sIgAD who had 
higher saliva IgM levels showed a lower infection incidence (47), although this was not found in a later study (46). Patients with sIgAD are usually not treated with IgG replacement therapy (IgGRT), but it is recommended for individuals with IgA deficiency and concomitant IgG2 subclass deficiency (48).

\section{Selective IgM Deficiency}

The European Society for Immunodeficiencies (ESID) Registry defines selective $\operatorname{IgM}$ deficiency (sIgMD) as a serum $\operatorname{IgM}$ concentration of 2 standard deviations below the normal level, with normal levels of serum IgA and IgG, normal vaccination responses and absence of $\mathrm{T}$ cell defects (41). The immunological and clinical phenotype of sIgMD is very heterogeneous and patients can remain asymptomatic (49). Similar to sIgAD, patients with sIgMD often present with recurrent respiratory problems $(49,50)$. In a cohort of 17 sIgMD patients, recurrent upper respiratory tract infections were observed in 5 out of 6 patients with undetectable IgM levels $(<0.05 \mathrm{~g} / \mathrm{L})(49)$. Although for most sIgMD patients IgGRT was not required (49), it is recommended for patients with recurrent or severe infections (51).

\section{Common Variable Immune Deficiencies}

Patients with common variable immune deficiencies (CVID) are characterized by a marked decrease of IgG or IgA with or without low IgM levels, poor specific immunoglobulin responses to vaccination and no profound T-cell deficiency (41). A monogenic cause has been identified in $2-10 \%$ of CVID patients, but most patients appear to be polygenic or multifactorial disorders (52). Most CVID patients present with infectious manifestations, commonly of the upper and lower respiratory tract (53). The majority (70\%) of CVID patients develop chronic pulmonary complications including bronchiectasis and bronchial wall thickening (54). To prevent especially respiratory tract infections, IgGRT is the mainstay treatment for CVID patients (55).

\section{Agammaglobulinemia}

Patients with agammaglobulinemia have very low or no serum immunoglobulin levels, making these patients highly susceptible to infections (2). The largest group of patients have X-linked agammaglobulinemia (XLA), which is a caused by a defect in the Btk gene encoding Bruton Tyrosine Kinsase (Btk), which accounts for $85 \%$ of agammaglobulinemia patients. IgGRT is recommended for all agammaglobulinemia patients to reduce infections (56). Bacterial infections of the respiratory tract are often seen in patients with agammaglobulinemia, prior to diagnosis, but also after initiation of IgGRT (57-60), likely due to the absence of IgA and IgM antibodies in IgGRT. As a results, a large proportion of agammaglobulinemia patients develop chronic lung diseases $(57,59)$.

\section{PAST, PRESENT AND FUTURE OF IMMUNOGLOBULIN REPLACEMENT THERAPY}

IgG for IgGRT is traditionally collected from the Cohn fraction II after cold methanol precipitation $(61,62)$ and used to prevent infections in patients with PID. Despite IgGRT, recurrent infections, mainly of the respiratory tract, are reported (5760 ), and is associated with a lowered life-expectancy of CVID and agammaglobulinemia patients $(63,64)$. Currently used immunoglobulin preparations contain only IgG. As a result, concurrent IgA and IgM deficiency persists in a large proportion of immunoglobulin deficient patients, which results in recurrent infections and development of chronic lung diseases such as bronchiectasis $(65,66)$. Here, we summarize the current and novel immunoglobulin replacement therapies possibly effective in preventing bacterial respiratory tract infections.

\section{In the Beginning; 1952}

IgGRT was first introduced in 1952 by Colonel Ogden Bruton and applied to the first patient with agammaglobulinemia (67). This patient had an extensive history of infections, including osteomyelitis, gastrointestinal infection, and multiple episodes of epidemic parotitis, otitis media, pneumonia and sepsis for 4.5 years. After the third episode of epidemic parotitis, it was found that the serum of this patient was deficient for immunoglobulins. The patient was given subcutaneous IgGRT (SC-IgGRT) and was free of invasive infections $(67,68)$. After this first success, more individuals with agammaglobulinemia and other PID were treated with IgGRT. Most patients received intramuscular IgGRT (IM-IgGRT) (60) because uptake and bioavailability of IgG from the muscle is better as compared to fatty tissue where it is deposited by SC-IgGRT (69). However, injections were painful and the volume that can be given is limited, therefore, alternative administration methods were explored.

An advantage for SC-IgGRT is the ability for home treatment, which was shown to be feasible and safe (70). Home treatment is more convenient, and prevents loss of school or workdays and hospital costs (70). Although SC-IgGRT was initially limited by a slow infusion, this improved considerably over the past years (71). Recently, a new SC-IgGRT formulation containing recombinant hyaluronidase, which is an enzyme that cleaves the extracellular matrix and increases tissue permeability. Therefore, the use of recombinant hyaluronidase enables administration of larger volumes of IgG and thereby decreases dosing frequency to once in the 3-4 weeks, is in clinical trial (72).

\section{Next Step, Intravenous IgG Replacement Therapy}

The largest disadvantage of both SC-IgGRT and IM-IgGRT is the limited volume that can be administered per dose. As a result, the patient requires frequent dosing, typically every week. With intravenous IgGRT (IV-IgGRT), larger volumes can be giving, which decreases the frequency of dosing to once in the 3-4 weeks. However, it requires venous access and the incidence of systemic adverse reactions were high in the early years, mainly due to vasomotor and cardiovascular manifestations, which was most likely due to immunoglobulin aggregation and complement activation $(56,73,74)$. Later, modification of IV-IgGRT by for instance $ß$-propiolactone, which prevents aggregation (75), reduced the number of side-effects considerably (76) and soon became the routine treatment regimen $(77,78)$. In a headto-head comparison, IV-IgGRT was given once every 4 weeks and SC-IgGRT every week. Significant improvement in clinical 
parameters such as a lower number of days with acute respiratory infections and IgG trough levels were found for IV-IgGRT (74). This even improved further when IV-IgGRT was given once every 3 weeks (74). Important for protection against respiratory infections, serum opsonic capacity of $H$. influenzae and $S$. pneumoniae increased when IV-IgGRT was administered once every 3 weeks as compared to once every 4 weeks (74).

\section{POSSIBLE IMPROVEMENTS; IgA- AND/OR IgM-ENRICHED IMMUNOGLOBULIN REPLACEMENT THERAPY}

Nowadays, both SC-IgGRT and IV-IgGRT are used to prevent infections in patients with PID and are proven to be safe (79). The choice of therapy is mainly based on the clinical condition of the patient, side effects and patient's preference, as SCIgGRT therapy can be administered by the patient at home independent of help from health care professionals. However, as mentioned above, the current IgGRT has an important limitation; it contains only IgG, resulting in the absence or low levels of IgA and/or IgM in patients with PID. Despite IgGRT, many patients with PID develop chronic lung disease $(57,59,66)$. Therefore, improvements in therapy are needed, which might be the addition of IgA and/or IgM.

There are a limited number of IgA- and/or IgM-enriched immunoglobulin preparations used in clinical practice. Here, we summarize studies that have used IgA- and/or IgM-enriched immunoglobulin products, mainly in treatment of acute bacterial infections in general and highlight the studies focused on infections in immunoglobulin deficient patients.

\section{Fresh Frozen Plasma}

Fresh frozen plasma (FFP) was advocated over IM-IgGRT by Richard Stiehm in 1975 (80) and was next to IM-IgGRT used in the early days (81). The IgG levels achieved with FFP treatment were significantly higher as compared to IM-IgGRT, while IgM and IgA levels were only slightly increased (80). The use of FFP has limited or no side effects, but to reach a normal level of IgA and IgM, it should be given at a high frequency $(\sim$ twice a week), which is inconvenient for the patient. FFP was also given to PID patients with chronic gastro-intestinal infections as addon therapy to their normal IgGRT. Two patients with relapsing Campylobacter jejuni infection were given FFP for 2 or 4 weeks (500 mL twice weekly), which resulted in complete recovery of both patients (82). Plasma infusion resulted in detectable serum IgA levels in two patients and detectable serum IgM levels in 1 patients (82). Although we have not found direct evidence, FFP might be beneficial as an treatment, next to normal IgGRT, to eliminate chronic bacterial respiratory tract infections.

\section{Pentaglobin}

Pentaglobin is an IgA- and IgM-containing immunoglobulin preparation collected from Cohn fraction III, consisting of $72 \% \operatorname{IgG}, 12 \% \operatorname{IgM}$, and 16\% IgA for intravenous use (83). Pentaglobin is treated with $ß$-propiolactone, which decreases immunoglobulin aggregation, but also affects complement fixation and Fc-binding capacity $(84,85)$. A clear beneficial effect of Pentoglobin in comparison to conventional intravenous $\operatorname{IgG}$ is its effective reduction of endotoxin $(86,87)$. Direct effects on bacterial killing has also been observed by in vitro experiments. For instance, Pentaglobin had a greater opsonic activity against Pseudomonas aeruginosa, Staphylococcus aureus and Escherichia coli, in comparison to $\operatorname{IV}-\operatorname{IgGRT}(88,89)$. In a $S$. aureus mouse sepsis model, the number of bacteria in liver and kidney were significantly lower for animals receiving Pentaglobin in comparison to animals receiving IV-IgGRT Intratect (89). Pentaglobin has to our knowledge not been used as replacement for conventional IgGRT, but, it has successfully been applied to treat two hypogammaglobulinemia patients with persistent gastroenteric C. jejuni infections (90). In these two patients, six dosages of Pentaglobin at 3-week intervals were well tolerated (90). After the first dose, an increased serum bactericidal antibody activity against $C$. jejuni was measured and treatment resulted in the elimination of the C. jejuni infections (90). This result is in line with the use of IgA- and IgM-containing FFP, which was also successfully used to treat chronic C. jejuni infections (82). We have found a remarkable increase in complement-mediated killing of C. jejuni (31) by supplementing purified serum IgM to serum of a patients with agammaglobulinemia, supporting an important role for IgM in complement-mediated protection against bacterial pathogens.

\section{Trimodulin}

Trimodulin (BT-588, predecessor BT-086) contains twice the amount of $\operatorname{IgA}(21 \%)$ and $\operatorname{IgM}(23 \%)$ in comparison to Pentaglobin. Trimodulin is not treated with $\beta$-propiolactone and showed approximately 10-fold increase in opsonization of E. coli compared to Pentaglobin (91). In a rabbit model for endotoxemia, Trimodulin showed an increased elimination of E. coli from the bloodstream (92). Recently, the results of a phase II trial, which included 160 patients with severe communityacquired pneumonia, were published (93). Although no difference was observed for ventilator-free days between the placebo and Trimodulin groups, post-hoc analyses supported improved outcome in patients with elevated CRP, reduced IgM, or both. In addition, Trimodulin seemed to prevent secondary bacterial infections because infection-related treatmentemergent adverse events were significantly decreased from 57\% in the placebo group to $33 \%$ in the Trimodulin-treated patients (93). Since IgA and IgM concentrations present in Trimodulin are higher compared to Pentaglobin, we would expect an additive effect on preventing bacterial infections of the respiratory tract, although this has not been determined to date.

\section{IgAbulin}

IgAbulin is an IgA-enriched IgG preparation, which was shown to prevent necrotizing enterocolitis when administered orally to babies with low birth weight (94) and has successfully been used to treat children with chronic diarrhea (95). Oral administration of IgAbulin daily for 3 weeks decreased the number of stools per day and improved the consistency of the stools (95). So far, IgA-enriched IgGRT has not been used to prevent or treat bacterial respiratory tract infections. Since IgA is the 
most abundant immunoglobulin isotype on the respiratory tract mucosal surface, with divers functions in preventing bacterial infections, it might help in preventing and clearing bacterial infections. A possible limitation of the current IgA-enriched immunoglobulin preparations is that they are isolated from plasma, and plasma-derived $\operatorname{IgA}$ is mainly $\operatorname{IgA} 1$, which is more sensitive to bacterial IgA proteases (96), in comparison to IgA2, which is most abundant on the mucosal surface (16). In addition, the majority of serum-derived IgA is monomeric (17), in contrast to locally produced IgA, which is mainly dimeric (16). But, administration of sufficient IgA might potentially be effective in preventing bacterial respiratory tract infections, especially in PID patients with concurrent IgA deficiency.

\section{Purified Serum IgA and IgM Linked to Recombinant Secretory Component}

Although not in clinical trials, plasma-derived IgA and IgM containing recombinant secretory component have been tested in animal studies with promising results. It has been shown that plasma-derived $\operatorname{IgA}$ and $\operatorname{IgM}$ can bind recombinant secretory component to form sIgA and $\operatorname{sgM}$ (97). Addition of the secretory component increased resistance to protease activity and showed to prevent Shigella flexneri-induced intestine epithelial cell damage in an in vitro cell model (98). sIgA and sIgM preparations were found to bind and agglutinate Salmonella enterica Typhimurium (99). Oral administration of sIgA and sIgM preparations effectively limited S. Typhimurium infection and systemic dissemination in mice (99). No results were published

\section{REFERENCES}

1. Hsu E, Pulham N, Rumfelt LL, Flajnik MF. The plasticity of immunoglobulin gene systems in evolution. Immunol Rev. (2006) 210:8-26. doi: 10.1111/j.0105-2896.2006.00366.x

2. Sullivan KE, Stiehm ER. Stiehm's Immune Deficiencies. London; San Diego, CA: Elsevier/AP (2014).

3. Janeway C. Immunobiology: the immune system in health and disease. New York, NY: Garland Science (2005).

4. Schroeder HW Jr, Cavacini L. Structure and function of immunoglobulins. J Allergy Clin Immunol. (2010) 125(2 Suppl. 2):S41-52. doi: 10.1016/j.jaci.2009.09.046

5. Mankarious S, Lee M, Fischer S, Pyun KH, Ochs HD, Oxelius VA, et al. The half-lives of IgG subclasses and specific antibodies in patients with primary immunodeficiency who are receiving intravenously administered immunoglobulin. J Lab Clin Med. (1988) 112:634-40.

6. Waldmann TA, Strober W. Metabolism of immunoglobulins. Prog Allergy (1969) 13:1-110.

7. Barth WF, Wochner RD, Waldmann TA, Fahey JL. Metabolism of human gamma macroglobulins. J Clin Invest. (1964) 43:1036-48. doi: $10.1172 /$ JCI104987

8. Bindon CI, Hale G, Bruggemann M, Waldmann H. Human monoclonal IgG isotypes differ in complement activating function at the level of $\mathrm{C} 4$ as well as C1q. J Exp Med. (1988) 168:127-42.

9. Tao MH, Smith RI, Morrison SL. Structural features of human immunoglobulin $\mathrm{G}$ that determine isotype-specific differences in complement activation. J Exp Med. (1993) 178:661-7.

10. Diebolder CA, Beurskens FJ, de Jong RN, Koning RI, Strumane K, Lindorfer MA, et al. Complement is activated by IgG hexamers assembled at the cell surface. Science (2014) 343:1260-3. doi: 10.1126/science.1248943 regarding the effects on protection of bacterial respiratory pathogens, but since these sIgA and sIgM preparations are able to block bacterial adhesion, it is expected to prevent acquisition of bacteria in the respiratory tract when applied to the airways. In addition, these $\operatorname{sg} A$ and $\operatorname{sgM}$ preparations are not treated with $ß$-propiolactone, preserving natural complement fixating activity. Future experiments are required to address the efficacy to prevent bacterial respiratory tract infections.

\section{CONCLUDING REMARKS}

Current IgGRT treatment has not shown to prevent bacterial respiratory tract infections in a selection of PID patients. Based on the clinical presentation of patients with IgA and IgM deficiencies, who mainly present with respiratory tract infections, it is conceivable that IgA- and/or IgM-enriched immunoglobulin replacement therapy with biologically active IgA and/or IgM have the potential to prevent these type of infections. In the near future, pre-clinical in vitro assays, animal experiments and clinical trials have to be conducted to determine whether IgA and/or IgM-enriched immunoglobulin replacement therapy would prevent bacterial respiratory tract infections in patients with PID.

\section{AUTHOR CONTRIBUTIONS}

JL wrote the initial manuscript. MvdF and MdJ edited and approved the final manuscript.

11. Pluschke G, Bordmann G, Daoudaki ME, Lambris JD, Achtman M, Neibert $\mathrm{M}$. Isolation of rat IgM to IgG hybridoma isotype switch variants and analysis of the efficiency of rat Ig in complement activation. Eur J Immunol. (1989) 19:131-5. doi: 10.1002/eji.1830190121

12. Raff HV, Bradley C, Brady W, Donaldson K, Lipsich L, Maloney G, et al. Comparison of functional activities between IgG1 and IgM classswitched human monoclonal antibodies reactive with group B streptococci or Escherichia coli K1. J Infect Dis. (1991) 163:346-54.

13. Sabharwal UK, Vaughan JH, Fong S, Bennett PH, Carson DA, Curd JG. Activation of the classical pathway of complement by rheumatoid factors. Assessment by radioimmunoassay for C4. Arthritis Rheum. (1982) 25:161-7.

14. Davis AC, Roux KH, Shulman MJ. On the structure of polymeric IgM. Eur J Immunol. (1988) 18:1001-8. doi: 10.1002/eji.1830180705

15. Frangione B, Wolfenstein MJ. Todel: partial duplication in the "hinge" region of IgA 1 myeloma proteins. Proc Natl Acad Sci USA. (1972) 69:3673-6.

16. Delacroix DL, Dive C, Rambaud JC, Vaerman JP. IgA subclasses in various secretions and in serum. Immunology (1982) 47:383-5.

17. Delacroix DL, Elkom KB, Geubel AP, Hodgson HF, Dive C, Vaerman JP. Changes in size, subclass, and metabolic properties of serum immunoglobulin A in liver diseases and in other diseases with high serum immunoglobulin A. J Clin Invest. (1983) 71:358-67.

18. Woof JM, Mestecky J. Mucosal immunoglobulins. Immunol Rev. (2005) 206:64-82. doi: 10.1111/j.0105-2896.2005.00290.x

19. Johnson S, Sypura WD, Gerding DN, Ewing SL, Janoff EN. Selective neutralization of a bacterial enterotoxin by serum immunoglobulin $\mathrm{A}$ in response to mucosal disease. Infect Immun. (1995) 63:3166-73.

20. Crago SS, Kulhavy R, Prince SJ, Mestecky J. Secretory component of epithelial cells is a surface receptor for polymeric immunoglobulins. J Exp Med. (1978) 147:1832-7. 
21. Brandtzaeg P, Prydz H. Direct evidence for an integrated function of J chain and secretory component in epithelial transport of immunoglobulins. Nature (1984) 311:71-3.

22. Mostov KE, Kraehenbuhl JP, Blobel G. Receptor-mediated transcellular transport of immunoglobulin: synthesis of secretory component as multiple and larger transmembrane forms. Proc Natl Acad Sci USA. (1980) 77:7 257-61.

23. Mostov KE, Blobel G. A transmembrane precursor of secretory component. The receptor for transcellular transport of polymeric immunoglobulins. J Biol Chem. (1982) 257:11816-21.

24. Underdown BJ, Dorrington KJ. Studies on the structural and conformational basis for the relative resistance of serum and secretory immunoglobulin A to proteolysis. J Immunol. (1974) 112:949-59.

25. Michaelsen TE, Emilsen S, Sandin RH, Granerud BK, Bratlie D, Ihle O, et al. Human secretory IgM antibodies activate human complement and offer protection at mucosal surface. Scand J Immunol. (2017) 85:43-50. doi: $10.1111 /$ sji. 12508

26. Simister NE, Rees AR. Isolation and characterization of an $\mathrm{Fc}$ receptor from neonatal rat small intestine. Eur J Immunol. (1985) 15:733-8. doi: 10.1002/eji.1830150718

27. Dickinson BL, Badizadegan K, Wu Z, Ahouse JC, Zhu X, Simister NE, et al. Bidirectional FcRn-dependent IgG transport in a polarized human intestinal epithelial cell line. J Clin Invest. (1999) 104:903-11. doi: 10.1172/ JCI6968

28. Ghetie V, Hubbard JG, Kim JK, Tsen MF, Lee Y, Ward ES. Abnormally short serum half-lives of IgG in beta 2-microglobulin-deficient mice. Eur J Immunol. (1996) 26:690-6. doi: 10.1002/eji.1830260327

29. Junghans RP, Anderson CL. The protection receptor for IgG catabolism is the beta2-microglobulin-containing neonatal intestinal transport receptor. Proc Natl Acad Sci USA. (1996) 93:5512-6.

30. Bisgard KM, Kao A, Leake J, Strebel PM, Perkins BA, Wharton M. Haemophilus influenzae invasive disease in the United States, 1994-1995: near disappearance of a vaccine-preventable childhood disease. Emerg Infect Dis. (1998) 4:229-37. doi: 10.3201/eid0402.980210

31. Langereis JD, Henriet SS, Kuipers S, Weemaes CMR, van der Burg M, de Jonge MI, et al. IgM augments complement bactericidal activity with serum from a patient with a novel CD79a mutation. J Clin Immunol. (2018) 38:185-92. doi: 10.1007/s10875-017-0474-7

32. Peltola H, Kilpi T, Anttila M. Rapid disappearance of Haemophilus influenzae type b meningitis after routine childhood immunisation with conjugate vaccines. Lancet (1992) 340:592-4.

33. van Alphen L, Spanjaard L, van der Ende A, Schuurman I, Dankert J. Effect of nationwide vaccination of 3-month-old infants in the Netherlands with conjugate Haemophilus influenzae type b vaccine: high efficacy and lack of herd immunity. J Pediatr. (1997) 131:869-73.

34. Ladhani SN. Two decades of experience with the haemophilus influenzae serotype b conjugate vaccine in the United Kingdom. Clin Ther. (2012) 34:385-99. doi: 10.1016/j.clinthera.2011.11.027

35. Barra A, Dagan R, Preud'homme JL, Bajart A, Danve B, Fritzell B. Characterization of the serum antibody response induced by Haemophilus influenzae type $\mathrm{b}$ tetanus protein-conjugate vaccine in infants receiving a DTP-combined vaccine from 2 months of age. Vaccine (1993) 11:1 003-6.

36. Bryant KA, Block SL, Baker SA, Gruber WC, Scott DA, PCVIS Group. Safety and immunogenicity of a 13-valent pneumococcal conjugate vaccine. Pediatrics (2010) 125:866-75. doi: 10.1542/ peds.2009-1405

37. Black S, Shinefield H, Fireman B, Lewis E, Ray P, Hansen JR, et al. Efficacy, safety, and immunogenicity of heptavalent pneumococcal conjugate vaccine in children. Am J Manag Care (2000) 6:S536-49. doi: 10.1097/00006454-200003000-00003

38. Eskola J, Kilpi T, Palmu A, Jokinen J, Haapakoski J, Herva E, et al. Efficacy of a pneumococcal conjugate vaccine against acute otitis media. New Eng J Med. (2001) 344:403-9. doi: 10.1056/Nejm200102083440602

39. Shinefield H, Black S, Ray P, Fireman B, Schwalbe J, Lewis E. Efficacy, immunogenicity and safety of heptavalent pneumococcal conjugate vaccine in low birth weight and preterm infants. Pediatr Infect Dis J. (2002) 21:182-6. doi: 10.1097/00006454-200203000-00003
40. van der Maten E, de Jonge MI, de Groot R, van der Flier M, Langereis JD. A versatile assay to determine bacterial and host factors contributing to opsonophagocytotic killing in hirudin-anticoagulated whole blood. Sci Rep. (2017) 7:42137. doi: 10.1038/srep42137

41. European Society for Immunodeficiencies. Registry-Diagnosis criteria, April 19th 2018. Available online at https://esid.org/Working-Parties/Registry/ Diagnosis-criteria

42. Abolhassani H, Aghamohammadi A, Hammarstrom L. Monogenic mutations associated with IgA deficiency. Expert Rev Clin Immunol. (2016) 12:1321-35. doi: 10.1080/1744666X.2016.1198696

43. Aghamohammadi A, Cheraghi T, Gharagozlou M, Movahedi M, Rezaei $\mathrm{N}$, Yeganeh $\mathrm{M}$, et al. IgA deficiency: correlation between clinical and immunological phenotypes. J Clin Immunol. (2009) 29:130-6. doi: 10.1007/s10875-008-9229-9

44. Burgio GR, Duse M, Monafo V, Ascione A, Nespoli L. Selective IgA deficiency: clinical and immunological evaluation of 50 pediatric patients. Eur J Pediatr. (1980) 133:101-6.

45. Aytekin C, Tuygun N, Gokce S, Dogu F, Ikinciogullari A. Selective IgA deficiency: clinical and laboratory features of 118 children in Turkey. J Clin Immunol. (2012) 32:961-6. doi: 10.1007/s10875-0129702-3

46. Norhagen G, Engstrom PE, Hammarstrom L, Soder PO, Smith CI. Immunoglobulin levels in saliva in individuals with selective IgA deficiency: compensatory IgM secretion and its correlation with HLA and susceptibility to infections. J Clin Immunol. (1989) 9:279-86.

47. Mellander L, Bjorkander J, Carlsson B, Hanson LA. Secretory antibodies in IgA-deficient and immunosuppressed individuals. J Clin Immunol. (1986) 6:284-91.

48. Orange JS, Hossny EM, Weiler CR, Ballow M, Berger M, Bonilla $\mathrm{FA}$, et al. Use of intravenous immunoglobulin in human disease: a review of evidence by members of the primary immunodeficiency committee of the american academy of allergy, asthma and immunology. J Allergy Clin Immunol. (2006) 117(4 Suppl):S525-53. doi: 10.1016/ j.jaci.2006.01.015

49. Chovancova Z, Kralickova P, Pejchalova A, Bloomfield M, Nechvatalova J, Vlkova $\mathrm{M}$, et al. Selective IgM deficiency: clinical and laboratory features of 17 patients and a review of the literature. J Clin Immunol. (2017) 37:559-74. doi: 10.1007/s10875-017-0420-8

50. Janssen LMA, Macken T, Creemers MCW, Pruijt JFM, Eijk JJJ, de Vries E. Truly selective primary IgM deficiency is probably very rare. Clin Exp Immunol. (2018) 191:203-11. doi: 10.1111/cei.13065

51. Gupta S, Gupta A. Selective IgM deficiency-an underestimated primary immunodeficiency. Front Immunol. (2017) 8:1056. doi: 10.3389/fimmu.2017.01056

52. Bogaert DJ, Dullaers M, Lambrecht BN, Vermaelen KY, De Baere E, Haerynck F. Genes associated with common variable immunodeficiency: one diagnosis to rule them all? J Med Genet. (2016) 53:575-90. doi: 10.1136/jmedgenet-2015-103690

53. Oksenhendler E, Gerard L, Fieschi C, Malphettes M, Mouillot G, Jaussaud R, et al. Infections in 252 patients with common variable immunodeficiency. Clin Infect Dis. (2008) 46:1547-54. doi: 10.1086/587669

54. Touw CM, van de Ven AA, de Jong PA, Terheggen-Lagro S, Beek E, Sanders EA, et al. Detection of pulmonary complications in common variable immunodeficiency. Pediatr Allergy Immunol. (2010) 21:793-805. doi: 10.1111/j.1399-3038.2009.00963.x

55. Busse PJ, Razvi S, Cunningham-Rundles C. Efficacy of intravenous immunoglobulin in the prevention of pneumonia in patients with common variable immunodeficiency. J Allergy Clin Immunol. (2002) 109:1001-4. doi: 10.1067/mai.2002.124999

56. Ammann AJ, Ashman RF, Buckley RH, Hardie WR, Krantmann HJ, Nelson $\mathrm{J}$, et al. Use of intravenous gamma-globulin in antibody immunodeficiency: results of a multicenter controlled trial. Clin Immunol Immunopathol. (1982) 22:60-7.

57. Plebani A, Soresina A, Rondelli R, Amato GM, Azzari C, Cardinale F, et al. Clinical, immunological, and molecular analysis in a large cohort of patients with X-linked agammaglobulinemia: an Italian multicenter study. Clin Immunol. (2002) 104:221-30. doi: 10.1006 clim.2002.5241 
58. Winkelstein JA, Marino MC, Lederman HM, Jones SM, Sullivan $\mathrm{K}$, Burks $\mathrm{AW}$, et al. X-linked agammaglobulinemia: report on a United States registry of 201 patients. Medicine (2006) 85:193-202. doi: 10.1097/01.md.0000229482.27398.ad

59. Basile N, Danielian S, Oleastro M, Rosenzweig S, Prieto E, Rossi J, et al. Clinical and molecular analysis of 49 patients with X-linked agammaglobulinemia from a single center in Argentina. J Clin Immunol. (2009) 29:123-9. doi: 10.1007/s10875-008-9227-y

60. Lederman HM, Winkelstein JA. X-linked agammaglobulinemia: an analysis of 96 patients. Medicine (1985) 64:145-56.

61. Cohn EJ, Strong LE, Hughes WL, Mulford DJ, Ashworth JN, Melin M, et al. Preparation and properties of serum and plasma proteins; a system for the separation into fractions of the protein and lipoprotein components of biological tissues and fluids. J Am Chem Soc. (1946) 68:459-75.

62. Oncley JL, Melin M, Richert DA, Cameron JW, Gross PM. The separation of the antibodies, isoagglutinins, prothrombin, plasminogen and beta1lipoprotein into subfractions of human plasma. J Am Chem Soc. (1949) 71:541-50.

63. Shillitoe B, Gennery A. X-Linked Agammaglobulinaemia: outcomes in the modern era. Clin Immunol. (2017) 183:54-62. doi: 10.1016/ j.clim.2017.07.008

64. Cunningham-Rundles C, Bodian C. Common variable immunodeficiency: clinical and immunological features of 248 patients. Clin Immunol. (1999) 92:34-48. doi: 10.1006/clim.1999.4725

65. Quinti I, Soresina A, Guerra A, Rondelli R, Spadaro G, Agostini C, et al. Effectiveness of immunoglobulin replacement therapy on clinical outcome in patients with primary antibody deficiencies: results from a multicenter prospective cohort study. J Clin Immunol. (2011) 31:315-22. doi: 10.1007/s10875-011-9511-0

66. Hodkinson JP, Bangs C, Wartenberg-Demand A, Bauhofer A, Langohr P, Buckland MS, et al. Low IgA and IgM Is associated with a higher prevalence of bronchiectasis in primary antibody deficiency. J Clin Immunol. (2017) 37:329-31. doi: 10.1007/s10875-01 7-0381-y

67. Bruton OC. Agammaglobulinemia. Pediatrics (1952) 9:722-8.

68. Bruton OC. A decade with agammaglobulinemia. J Pediatr. (1962) 60:672-6.

69. Smith GN, Griffiths B, Mollison D, Mollison PL. Uptake of IgG after intramuscular and subcutaneous injection. Lancet (1972) $1: 1208-12$.

70. Ochs HD, Fischer SH, Lee ML, Delson ES, Kingdon HS, Wedgwood RJ. Intravenous immunoglobulin home treatment for patients with primary immunodeficiency diseases. Lancet (1986) 1:610-11.

71. Gardulf A, Hammarstrom L, Smith CI. Home treatment of hypogammaglobulinaemia with subcutaneous gammaglobulin by rapid infusion. Lancet (1991) 338:162-6.

72. Wasserman RL, Melamed I, Kobrynski L, Puck J, Gupta S, Doralt J, et al. Recombinant human hyaluronidase facilitated subcutaneous immunoglobulin treatment in pediatric patients with primary immunodeficiencies: long-term efficacy, safety and tolerability. Immunotherapy (2016) 8:1175-86. doi: 10.2217/imt-2016-0066

73. Barandun S, Kistler P, Jeunet F, Isliker H. Intravenous administration of human gamma-globulin. Vox Sang. (1962) 7:157-74.

74. Garbett ND, Currie DC, Cole PJ. Comparison of the clinical efficacy and safety of an intramuscular and an intravenous immunoglobulin preparation for replacement therapy in idiopathic adult onset panhypogammaglobulinaemia. Clin Exp Immunol. (1989) 76:1-7.

75. Stephan W. Undegraded human immunoglobulin for intravenous use. Vox Sang. (1975) 28:422-37.

76. Brennan VM, Salome-Bentley NJ, Chapel HMS. Immunology Nurses. Prospective audit of adverse reactions occurring in 459 primary antibody-deficient patients receiving intravenous immunoglobulin. Clin Exp Immunol. (2003) 133:247-51. doi: 10.1046/j.1365-2249.2003.0 2199.x

77. Nolte MT, Pirofsky B, Gerritz GA, Golding B. Intravenous immunoglobulin therapy for antibody deficiency. Clin Exp Immunol. (1979) 36:237-43.

78. Jager BV. Intravenous administration of modified gamma globulin. Several studies on a patient with agammaglobulinemia. Arch Intern Med. (1967) 119:60-4.
79. Gardulf A, Nicolay U, Asensio O, Bernatowska E, Bock A, Carvalho BC, et al. Rapid subcutaneous IgG replacement therapy is effective and safe in children and adults with primary immunodeficiencies-a prospective, multi-national study. J Clin Immunol. (2006) 26:177-85. doi: 10.1007/ s10875-006-9002-x

80. Stiehm ER. Plasma therapy: an alternative to gamma globulin injections in immunodeficiency. Birth Defects Orig Artic Ser. (1975) 11:343-6.

81. Buckley RH. Plasma therapy in immunodeficiency diseases. Am J Dis Child. (1972) 124:376-81.

82. Kerstens PJ, Endtz HP, Meis JF, Oyen WJ, Koopman RJ, van den Broek PJ, van der Meer JW. Erysipelas-like skin lesions associated with Campylobacter jejuni septicemia in patients with hypogammaglobulinemia. Eur $J$ Clin Microbiol Infect Dis. (1992) 11:842-7.

83. Stephan W, Dichtelmuller H, Schedel I. Properties and efficacy of a human immunoglobulin $\mathrm{M}$ preparation for intravenous administration. Arzneimittelforschung (1985) 35:933-6.

84. Stephan W. [Elimination of complement fixation of gamma-globulin by chemical modification with beta-propiolactone]. Z Klin Chem Klin Biochem. (1969) 7:282-6.

85. Jungi TW, Santer M, Lerch PG, Barandun S. Effect of various treatments of gamma-globulin (Igg) for achieving intravenous tolerance on the capacity to interact with human monocyte Fc-receptors - a comparativestudy. Vox Sang. (1986) 51:18-26. doi: 10.1111/j.1423-0410.1986.tb 00203.x

86. Wand S, Klages M, Kirbach C, Warszawska J, Meybohm P, Zacharowski $\mathrm{K}$, et al. IgM-enriched immunoglobulin attenuates systemic endotoxin activity in early severe sepsis: a before-after cohort study. PLoS ONE (2016) 11:e0160907. doi: 10.1371/journal.pone.01 60907

87. Behre G, Schedel I, Nentwig B, Wormann B, Essink M, Hiddemann W. Endotoxin concentration in neutropenic patients with suspected gramnegative sepsis: correlation with clinical outcome and determination of anti-endotoxin core antibodies during therapy with polyclonal immunoglobulin M-enriched immunoglobulins. Antimicrob Agents Chemother. (1992) 36:2139-46.

88. Garbett ND, Munro CS, Cole PJ. Opsonic activity of a new intravenous immunoglobulin preparation: pentaglobin compared with sandoglobulin. Clin Exp Immunol. (1989) 76:8-12.

89. Rossmann FS, Kropec A, Laverde D, Saaverda FR, Wobser D, Huebner $\mathrm{J}$. In vitro and in vivo activity of hyperimmune globulin preparations against multiresistant nosocomial pathogens. Infection (2015) 43:169-75. doi: 10.1007/s15010-014-0706-1

90. Borleffs JC, Schellekens JF, Brouwer E, Rozenberg-Arska M. Use of an immunoglobulin $\mathrm{M}$ containing preparation for treatment of two hypogammaglobulinemic patients with persistent Campylobacter jejuni infection. Eur J Clin Microbiol Infect Dis. (1993) 12:772-5.

91. Langohr PL, Wartenberg-Demand, A, Ulrike W, Daelken, B. Treatment of severe community acquired pneumonia. In: BIOTEST AG (Dreieich) (2017). Available online at: http://www.freepatentsonline.com/ WO2017157850.html

92. Shmygalev S, Damm M, Knels L, Strassburg A, Wunsche K, Dumke R, et al. IgM-enriched solution BT086 improves host defense capacity and energy store preservation in a rabbit model of endotoxemia. Acta Anaesthesiol Scand. (2016) 60:502-12. doi: 10.1111/aas.12652

93. Welte $T$, Dellinger RP, Ebelt $H$, Ferrer $M$, Opal SM, Singer $M$ et al. Efficacy and safety of trimodulin, a novel polyclonal antibody preparation, in patients with severe community-acquired pneumonia: a randomized, placebo-controlled, double-blind, multicenter, phase II trial (CIGMA study). Intensive Care Med. (2018) 44:438-48. doi: 10.1007/ s00134-018-5143-7

94. Eibl MM, Wolf HM, Furnkranz H, Rosenkranz A. Prevention of necrotizing enterocolitis in low-birth-weight infants by $\operatorname{IgA}$ - $\operatorname{IgG}$ feeding. N Engl J Med. (1988) 319:1-7. doi: 10.1056/NEJM1988070731 90101

95. Casswall TH, Hammarstrom L, Veress B, Nord CE, Bogstedt A, Brockstedt U, et al. Oral IgA-IgG treatment of chronic non-specific diarrhoea in infants and children. Acta Paediatr. (1996) 85:1126-8. 
96. Plaut AG, Wistar RJr, Capra JD. Differential susceptibility of human IgA immunoglobulins to streptococcal IgA protease. J Clin Invest. (1974) 54:1295-300. doi: 10.1172/JCI107875

97. Longet S, Miled S, Lotscher M, Miescher SM, Zuercher AW, Corthesy B. Human plasma-derived polymeric IgA and $\operatorname{IgM}$ antibodies associate with secretory component to yield biologically active secretory-like antibodies. J Biol Chem. (2013) 288:4085-94. doi: 10.1074/jbc.M112.4 10811

98. Longet S, Vonarburg C, Lotscher M, Miescher S, Zuercher A, Corthesy B. Reconstituted human polyclonal plasma-derived secretorylike $\operatorname{IgM}$ and $\operatorname{IgA}$ maintain the barrier function of epithelial cells infected with an enteropathogen. J Biol Chem. (2014) 289:21617-26. doi: 10.1074/jbc.M114.549139

99. Bioley G, Monnerat J, Lotscher M, Vonarburg C, Zuercher A, Corthesy B. Plasma-derived polyreactive secretory-like $\operatorname{IgA}$ and $\operatorname{IgM}$ opsonizing
Salmonella enterica typhimurium reduces invasion and gut tissue inflammation through agglutination. Front Immunol. (2017) 8:1043. doi: $10.3389 /$ fimmu.2017.01043

Conflict of Interest Statement: The authors declare that the research was conducted in the absence of any commercial or financial relationships that could be construed as a potential conflict of interest.

Copyright (C) 2018 Langereis, van der Flier and de Jonge. This is an open-access article distributed under the terms of the Creative Commons Attribution License (CC $B Y)$. The use, distribution or reproduction in other forums is permitted, provided the original author(s) and the copyright owner(s) are credited and that the original publication in this journal is cited, in accordance with accepted academic practice. No use, distribution or reproduction is permitted which does not comply with these terms. 